\title{
Review \\ Outcomes of Lower Extremity Endovascular Revascularization: Potential Predictors and Prevention Strategies
}

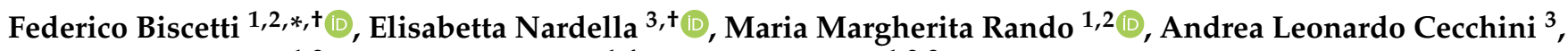 \\ Antonio Gasbarrini ${ }^{1,3}$, Massimo Massetti ${ }^{1,4}$ and Andrea Flex ${ }^{1,2,3}$ \\ 1 Fondazione Policlinico Universitario A. Gemelli IRCCS, 00168 Roma, Italy; \\ m.margheritarando@gmail.com (M.M.R.); antonio.gasbarrini@unicatt.it (A.G.); \\ massimo.massetti@unicatt.it (M.M.); andrea.flex@unicatt.it (A.F.) \\ 2 Cardiovascular Internal Medicine Unit, Fondazione Policlinico Universitario A. Gemelli IRCCS, \\ 00168 Roma, Italy \\ 3 Department of Medical and Surgical Sciences, Università Cattolica del Sacro Cuore, 00168 Roma, Italy; \\ elisabetta.nardella@gmail.com (E.N.); alcech92@gmail.com (A.L.C.) \\ 4 Department of Cardiovascular Sciences, Fondazione Policlinico Universitario A. Gemelli IRCCS, \\ 00168 Roma, Italy \\ * Correspondence: f.biscetti@gmail.com; Tel.: +39-06-3015-3148; Fax: +39-06-3550-7232 \\ + These authors contributed equally to this work.
}

check for

updates

Citation: Biscetti, F.; Nardella, E.; Rando, M.M.; Cecchini, A.L.; Gasbarrini, A.; Massetti, M.; Flex, A. Outcomes of Lower Extremity Endovascular Revascularization: Potential Predictors and Prevention Strategies. Int. J. Mol. Sci. 2021, 22, 2002. https://doi.org/10.3390/ ijms22042002

Academic Editors:

Hideyuki Yamawaki, Ayotunde O. Dokun and Mitsuharu Okutsu Received: 29 December 2020

Accepted: 12 February 2021

Published: 18 February 2021

Publisher's Note: MDPI stays neutral with regard to jurisdictional claims in published maps and institutional affiliations.

Copyright: (c) 2021 by the authors. Licensee MDPI, Basel, Switzerland. This article is an open access article distributed under the terms and conditions of the Creative Commons Attribution (CC BY) license (https:// creativecommons.org/licenses/by/ $4.0 /)$.

\begin{abstract}
Peripheral artery disease (PAD) is a manifestation of atherosclerosis, which may affect arteries of the lower extremities. The most dangerous PAD complication is chronic limb-threatening ischemia (CLTI). Without revascularization, CLTI often causes limb loss. However, neither open surgical revascularization nor endovascular treatment (EVT) ensure long-term success and freedom from restenosis and revascularization failure. In recent years, EVT has gained growing acceptance among all vascular specialties, becoming the primary approach of revascularization in patients with CLTI. In clinical practice, different clinical outcomes after EVT in patients with similar comorbidities undergoing the same procedure (in terms of revascularization technique and localization of the disease) cause unsolved issues that need to be addressed. Nowadays, risk management of revascularization failure is one of the major challenges in the vascular field. The aim of this literature review is to identify potential predictors for lower extremity endovascular revascularization outcomes and possible prevention strategies.
\end{abstract}

Keywords: peripheral artery disease (PAD); chronic limb-threatening ischemia (CLTI); revascularization

\section{Introduction}

Peripheral artery disease (PAD) is a manifestation of atherosclerosis disease, which may affect arteries in the lower extremities. It is the third most common manifestation of atherosclerosis after coronary artery disease (CAD) and stroke [1]. Fatigue, atypical leg pain, and cramping during ambulation-known as intermittent claudication (IC)—are typical signs of symptomatic PAD [2]. The most dangerous complication of PAD is critical limb ischemia (CLI), which is nowadays defined as chronic limb-threatening ischemia (CLTI) to include a wider and more heterogeneous group of patients with varying degrees of ischemia. The diagnosis of CLTI requires a documented atherosclerotic PAD associated with ischemic rest pain or tissue loss (ulceration or gangrene) [3].

It is estimated that over 230 million persons have PAD worldwide [4]. PAD may implicate a reduced functional capacity with an inevitable worsening in quality of life. Moreover, it is also associated with an increased risk for cardiovascular morbidity and mortality [5]. Therefore, PAD represents a major public health problem with a significant impact on healthcare causing a notable economic burden [6]. 
Without revascularization, CLTI often results in limb loss. However, neither open surgical revascularization nor endovascular treatment (EVT) guarantee treatment success and freedom from restenosis and revascularization failure [7,8]. In recent years, EVT has gained growing acceptance among all vascular specialties, becoming the primary approach of revascularization in patients with CLTI [9-11]. In clinical practice, different clinical outcomes after EVT in patients with similar comorbidities undergoing the same procedure (in terms of revascularization technique and localization of the disease) cause unsolved issues that need to be addressed [12]. Nowadays, the risk management of revascularization failure is one of the major challenges in the vascular field. The aim of this literature review is to identify potential predictors of lower extremity endovascular revascularization (LER) failure and possible prevention strategies.

\section{Definitions of Revascularization Failure}

Effective revascularization is defined by criteria for both anatomic and hemodynamic success. Indeed, a procedure may be technically successful and clinically unsuccessful. Some approaches may produce a better anatomic result without improving hemodynamics [13].

The endpoints of revascularization are classified into three categories: primary patency, primary-assisted patency, and secondary patency [14]. Primary patency is defined as continuous patency without directly performing an intervention or procedure. Primaryassisted patency is defined as uninterrupted patency, but it is maintained by prophylactic intervention. Secondary patency is the time from the procedure to restenosis [7]. The definition of restenosis is when the luminal diameter is narrowed by over $50 \%$ or the crosssectional area is reduced by over 75\% [15]. The complex pathophysiologic mechanism remains incompletely understood. Angioplasty, stent placement, or atherectomy represent a mechanical injury to the vessel, which locally reacts with an inflammatory response. This process may lead to restenosis because of intimal thickening and an increased extracellular matrix $[16,17]$. Neointimal hyperplasia acts as a main restenosis trigger after stenting. Instead, restenosis after angioplasty or atherectomy results from a combination of constrictive arterial remodeling along with neointimal hyperplasia [18-22].

Currently, endovascular angioplasty includes different techniques such as plain old balloon angioplasty, cryoplasty, cutting balloon angioplasty, and medicated balloon angioplasty. Self-expanding and balloon-expandable are two general types of stents. They are available with or without polytetrafluoroethylene cover, are bioabsorbable, and drug eluting [15]. These technologies were developed mainly to reduce restenosis rates after EVT. However, the discussion of technical considerations is in intentional scientific articles limited and therefore, also in this article restrictedly addressed [3].

Other important outcomes after LER are major adverse limb events (MALE)—defined as composite of acute limb ischemia, major vascular amputations, limb-threatening ischemia leading to urgent revascularization-and major adverse cardiovascular events (MACE) — defined as a composite of acute myocardial infarction, stroke, transient ischemic attack, and cardiovascular death [23,24].

\section{Revascularization: When Is It Appropriate?}

The goals of EVT in patients affected by PAD are pain relief, wound healing, and functional limb preservation. Nevertheless, revascularization may cause morbidity, which is correlated to many hospital admissions, continuous outpatient care, and significant treatment and health care costs, as well as mortality. Some patients can be appropriately treated with primary amputation or palliative care after multidisciplinary decision-making [3]. Therefore, patients for whom EVT may be beneficial need to be identified to avoid potential failure. Predicting functional outcomes after revascularization is difficult, particularly in patients who are severely deconditioned. The Global Vascular Guidelines (GVG) suggests a structured approach based on a three-step process: patient risk estimation, limb severity, and anatomic pattern of disease (PLAN) [3]. 


\subsection{Patient Risk Estimation}

CLTI affects patients with advanced age and multiple comorbidities. In this setting, estimation of operative risk and life expectancy is pivotal. Preoperative cardiac and anesthetic evaluation before limb revascularization is mandatory $[3,25,26]$. Several procedural risk factors have been identified for the CLTI population. They include advanced age (over 75 or 80 years), $\mathrm{CAD}$, congestive heart failure, diabetes mellitus (DM), chronic kidney disease (CKD), smoking, cerebrovascular disease, tissue loss, body max index (BMI), dementia, functional status, and frailty. In recent years, multiple risk stratification tools have been retrospectively developed for patients who underwent surgical revascularization [3,27-34], but none has been tested prospectively and endorsed by international guidelines.

\subsection{Limb Severity}

Patients affected by CLTI present a wide-ranging disease severity. The GVG recommends the Society for Vascular Surgery (SVS) threatened limb classification system integrating wound severity, ischemia, and foot infection (WIfI) to stage CLTI [35-38]. The classification grades each component from 0 to 3 , and a higher number indicates an increasing severity. Sixty-four theoretical patient combinations exist, with four possible clinical stages, ranging from a very low to a high amputation risk and revascularization benefit, respectively. WIfI has shown accuracy in predicting amputation risk and revascularization benefit $[39,40]$. Mayor et al. demonstrated that WIfI allows identifying which group of patients affected by CLTI may benefit from revascularization [41].

\subsection{Anatomic Pattern of Disease}

The third step of PLAN is the definition of an anatomic disease pattern. The traditional anatomic classification systems for PAD are lesion or segment focused [42,43]. The GVG propose a new approach named global limb anatomic staging system (GLASS) to integrate patterns of disease, hemodynamic improvement after treatment, anatomic durability, clinical stage, and outcomes [3]. This limb anatomic system introduces two novel concepts, which are the target arterial path (TAP) and the estimated limb-based patency (LBP), which is defined as patency along the TAP. GLASS describes three complexity stages for intervention derived from combined femoropopliteal and infrapopliteal GLASS grades (1-4), which represent increasing severity and disease complexity along the TAP [3]. GLASS stages are related to disease complexity for endovascular treatment (EVT), to immediate technical failure, and to one year LBP of the TAP [44]. Kodama et al. examined the relationship between GLASS and clinical outcomes in the Bypass versus Angioplasty in Severe Ischaemia of the Leg (BASIL)-1 trial patient cohort and found that GLASS was associated with EVT outcomes but not with bypass surgery [44]. This new limb-integrated system may facilitate both shared decision-making and CLTI patient stratification.

\section{The Unsolved Conundrum of Controlling Risk Factors}

Despite GVG providing an innovative approach with PLAN, the incidence of LER failure is still high.

The PAD population is characterized by some risk factors, which contribute to develop CLTI and cause worse outcomes after LER. For some of these risk factors, established therapeutic and pharmacological patient management strategies exist. For example, international guidelines recommend the use of moderate- to high-intensity statin therapy, because it is associated with significantly improved survival and with a lower MALE rate in patients undergoing revascularization for CLTI $[3,45]$. The adverse impact of tobacco use on cardiovascular outcomes has been well established. It is universally recognized that stopping smoking and adopting a healthy diet, weight control, and regular exercise are very important for both life and limb [3]. Nevertheless, current therapeutic strategies, in some conditions, are not associated with reduced LER failure. These conditions are well-recognized, but their pathogenic mechanism is not fully understood in patients with 
CLTI undergoing EVT. Therefore, it is essential to improve knowledge and to identify effective strategies.

\subsection{Management of Hypertension}

Although optimal blood pressure control for patients with CLTI has not been established, it is unanimously accepted that hypertension control reduces MACE in patients with PAD $[3,46]$. Moreover, several studies documented that angiotensin-converting enzyme inhibitors (ACEI) are associated with reduced MACE [47-49]. A study showed that patients with CLTI treated with ACEI and LER resulted in statistically significant more amputations, which remained significant after adjustment at 1 year [50]. Other studies found that ACEI use was associated with an increased rate of re-intervention [51]. Recently, Khan et al. [52] showed that ACEI use is associated with improved limb salvage rates in CLTI patients undergoing infrapopliteal but not femoropopliteal interventions, but no effects of ACEI on patency rates were found. The use of beta-blockers is traditionally contraindicated in patients with PAD due to concerns regarding reduced peripheral perfusion [53,54]. A Cochrane and a meta-analysis showed that beta-blockers do not worsen leg ischemia in patients with IC $[55,56]$. Long-term results of large prospective trials in patients with CLTI treated with ACEI and beta-blockers treatment are required to better understand the effects of these drugs on this population.

\subsection{Glycemic Control}

Diabetes mellitus (DM) represents the major risk factors of PAD [57-59]. A metaanalysis highlights that DM, independently from other major risk factors, increases vascular risk in both men and women [60]. Diabetes leads to endothelial dysfunction, vascular smooth muscle cell proliferation, and platelet activation [61]. Diabetic patients may have aggressive below-the-knee PAD and chronic CLTI $[3,62,63]$. Patients with PAD and DM have a major amputation risk which is 10 times higher than those without DM $[64,65]$. The extent of vascular disease is related to the duration and severity of hyperglycemia [66-68]. Current clinical guidelines recommended adequate glycemic control in diabetic patients to manage PAD $[3,69,70]$. However, the effects of intensive glucose control on the macrovascular outcomes among diabetic patients are controversial [71]. In randomized trials, tight glucose control in diabetic patients did not reduce MACE compared with standard glucose management [72-74]. Nevertheless, several post hoc analyses demonstrated that higher glycated hemoglobin (HbA1c) levels were associated with increased MACE [75] and MALE risks $[76,77]$. Two single-center studies suggested that poor glycemic control at the time of peripheral angioplasty was associated with worse clinical outcomes in patients with CLTI $[78,79]$. A retrospective analysis of US veterans affected by CLTI undergoing EVT showed that patients with poor glycemic control were at higher risk of amputation and MALE than those with good glycemic control [66]. Recently, Cha et al. reported, using data of a Korean multicenter retrospective registry cohort, the association between the preprocedural glycemic control based on $\mathrm{HbA1c}$ during index admission and clinical outcomes in diabetic patients undergoing EVT for PAD [80]. The suboptimal glycemic control group $(\mathrm{HbA1c} \geq 7.0)$ had a higher MALE incidence compared with the optimal glycemic control group (HbA1c $<7.0)$. Suboptimal glycemic control was an independent predictor of re-intervention during the follow-up period after EVT in diabetic patients with PAD [80]. The authors further analyzed data dividing into the presence of IC and CLTI. They found that suboptimal pre-procedural HbA1c did not affect the outcome in CLTI patients, whereas the incidence of MALE increased significantly among those with IC. This result is in accordance with our experience in which we found no correlation between $\mathrm{HbA1c}$ and fasting blood glucose (FBG) with the outcomes of diabetic patients with CLTI undergoing EVT [12]. Singh et al. hypothesized that disease severity is particularly critical at the time of EVT in which a better glycemic index has no discernable effect on clinical outcomes [81]. Moreover, several pieces of evidence suggested that glycemic variability 
may play a very important role in the atherosclerosis pathogenesis, independent of $\mathrm{HbA} 1 \mathrm{c}$ level [82-84].

Large prospective randomized trials will be needed to better understand optimal preoperative glycemic control in diabetic patients with PAD undergoing EVT.

Moreover, evidence showed that frequent $\mathrm{HbA} 1 \mathrm{c}$ monitoring, in the outpatient setting, improved long-term limb salvage and readmission rates in patients undergoing EVT [85]. Currently, the optimal target of $\mathrm{HbA1c}$ or FBG for this population is unknown, and the hypoglycemic pharmacological strategies are not standardized. Recent studies have shown that novel glucose-lowering agents may reduce the risk of cardiovascular events in patients with atherosclerotic disease [86,87]. However, increased risk of lower limb amputation has been described for sodium-glucose cotransporter type-2 inhibitors in patients with PAD [88,89]. The mechanism is unknown. Potier et al. described a possible correlation with diuretics and a significant risk increase in lower limb events, especially lower limb amputation [90]. Several studies examined the effects of dipeptidyl peptidase 4 inhibitors use on the risk of MACE (for a review, see [91]), but the impact on patients with CLTI and MALE has not been evaluated. Indeed, studies on hypoglycemic drugs classes are designed to evaluate the effects on outcomes of MACE. Further investigations are required, which evaluate MALE outcomes.

\subsection{Chronic Kidney Disease}

CKD is common in patients affected by PAD [92,93]. PAD and CKD have the same risk factors, such as diabetes, hypertension, dyslipidemia, advanced age, and smoking [94]. At the same time, PAD is prevalent in patients with CKD [95], especially among those with end-stage renal disease (ESRD) [96,97]. The 2005 kidney disease outcomes quality initiative guidelines recommend screening for PAD at the time of dialysis initiation [98,99].

Although CKD is an independent risk factor for PAD [98,100], it remains underestimated in current clinic guidelines [101]. Moreover, renal impairment is an important predictor of poor outcomes [94]. In a recent analysis, Smilowitz et al. examined a large representative national cohort from the United States undergoing surgical or endovascular revascularization for PAD with and without CKD or ESRD [102]. They found that CKD and ESRD were associated with a 74\% increased risk of perioperative MACE in patients undergoing both endovascular and surgical lower extremity revascularization. Lower extremity amputation occurred more frequently in patients with PAD and renal disease. Moreover, patients with renal disease required more hospital readmission within 6 months compared to those without renal disease [102]. In this analysis, the most common indications for hospital readmission were cardiovascular disease, endocrine/metabolic issues, and infectious complications. Indeed, CKD is a condition related to increased infection risk owing to functional immunosuppression ascribed to decreased glomerular filtration rate (GFR) and albuminuria [103].

A cross-sectional analysis of the US Renal Data System identified kidney-specific risk factors of PAD such as dialysis duration, hypoalbuminemia, hyperphosphatemia, inflammation, and malnutrition [104]. The typical feature of PAD in patients with CKD is diffuse calcified atherosclerosis caused by inflammation with oxidative stress, impaired angiogenesis, and uremic vasculopathy [105]. The presence of calcified lesions, in particular arterial intima calcification, represents a challenge for both surgical and endovascular therapy [106]. Therefore, calcification is a predictor for restenosis and revascularization failure [94]. EVT is often ineffective because of dissection and perforation risks, as well as the necessity to perform adjuvant atherectomy that may lead to distal embolization. No large randomized studies compared percutaneous versus surgical revascularization techniques in CKD patients with PAD. However, most of the available studies suggest that EVT is a reasonable first-line treatment in patients with CLTI and CKD, although outcomes are worse among patients with higher rates of repeated percutaneous angioplasty, subsequent surgical revascularization, or limb loss and death [107-115]. Perioperative 
morbidity and mortality are higher among CKD and dialyzed patients undergoing surgical procedures [95]; therefore, percutaneous methods are preferred [30,116-118].

Prevention, early diagnosis, and treatment of risk factors are key elements to improve outcomes in patients with CLTI and renal impairment, as well as the development of novel endovascular technologies to address vascular calcification.

\subsection{Functional Status}

Currently, no validated tools exist to assess grade and consider functional status, which is a major consideration during limb salvage decision. Khan et al. propose a functional outpatient score in patients affected by CLTI using a numeric scoring system in which score 0 indicates that the patients can walk outside his/her home with or without assistance; score 1 describes a patient who is able to walk only at home with/without assistance, score 2 indicates a patient with minimal ambulation ability, limbs are used for transfers, and score 3 describes a bed-bound patient [119].

The authors recommend applying this functional outpatient status as an adjunctive clinical decision-making tool to the current WIfI system to determine who may benefit most from revascularization with the goal of preserving baseline outpatient status [119]. Indeed, WIfI stages the limb, but not the patient, which is analogous to TNM staging for cancer. The goal is to not only to save limbs but also to guarantee optimal functional outcome. How to solve the functional status to unravel the CLTI puzzle is intricate and requires further studies with data on long-term outcomes [120].

\section{The Inflammatory State in CLTI}

The progression of atherosclerosis is characterized by an inflammatory reaction orchestrated by several molecules belonging to different families of inflammatory mediators, such as cytokines, chemokines, adhesion molecules, and proteolytic enzymes [121-123]. Similarly, diabetes and its complications cause a chronic, low-grade inflammatory status $[124,125]$. Based on this knowledge, Signorelli et al. investigated the plasma levels of inflammatory markers such as interleukin (IL)- 6 and tumor necrosis factor (TNF)- $\alpha$ in patients with PAD and in healthy controls [126]. They found, in agreement with previous findings [127], that patients with PAD show an inflammation marker profile different from that of controls. In literature, data regarding markers of inflammation and EVT outcomes in patients with PAD are presented. Barani et al. found that the inflammatory mediators IL-6, TNF- $\alpha$, N, and high-sensitivity C-reactive protein (CRP) were associated with 1-year mortality in CLTI patients [128]. For TNF- $\alpha$ and N, this association was independent of other variables such as age, sex, gangrene, active treatment, lipid-lowering therapy, leukocyte count, renal function, and cholesterol levels. Schillinger et al. demonstrated that pre- and post-intervention CRP levels were associated with restenosis after percutaneous transluminal angioplasty (PTA) of the distal popliteal and tibio-peroneal arteries, which indicates that inflammation plays a crucial role in the pathophysiology process [129]. Higher CRP levels were also found in diabetic patients who underwent PTA of the lower limb [130]. Bleda et al. analyzed the possible association between CRP and fibrinogen before EVT and during 1-year follow-up as well as its variation during the study period [131]. They found a significant correlation between basal levels of CRP and fibrinogen and the incidence of re-intervention, cardiovascular events, and death during follow-up. Moreover, Stone et al. found that after lower extremity endovascular interventions, elevated preprocedural CRP levels are associated with MALE and elevated levels of CRP and BNP are associated with late cardiovascular events [132].

Given these previous data, we hypothesized a correlation between osteoprotegerin (OPG), TNF- $\alpha$, IL-6, and CRP levels at baseline before EVT and outcomes in patients with diabetes, PAD, and CLTI [12]. Indeed, OPG is a recognized marker of atherosclerosis in diabetic patients, has a role in calcium metabolism, and directly interacts with the vascular endothelium [133-136]. TNF- $\alpha$ has a pivotal role in the pathway of diabetic atherosclerosis [61]. IL-6 has positive effects on endothelial function and aortic stiffness, 
as demonstrated by data from patients treated with IL-6 inhibitors [137]. CRP improves foam cell formation in atherosclerotic plaque and promotes platelet adhesion [138]. In our study, we found a significant linear trend between increasing levels of each cytokine and risk of MALE and MACE in patients with diabetes, PAD, and CLTI who underwent an endovascular procedure [12].

In addition, high mobility group box-1 (HMGB-1) is a nuclear protein that controls gene expression and starts pro-inflammatory responses in damaged and necrotic endothelial cells, taking part in inflammatory pathways [139-141]. Studies described a relationship between HMGB-1 levels, diabetes, and its complications [142]. Oozawa et al. found increased HMGB1 plasma levels in diabetic patients with PAD [143]. We demonstrated in a large population of diabetic patients that HMGB-1 plasma levels are significantly increased in patients affected by PAD with a positive correlation with clinical severity of vascular damage [136].

Assessment of the inflammatory state, quantifying serum cytokines, may support physicians to identify a subset of patients more susceptible to failure after the EVT.

The possibility that anti-inflammatory therapy can improve outcomes of LER should be investigated.

\section{Novel Biomarkers in CLTI}

In recent years, a growing number of plasma biomarkers have been tested as prognostic tools for diabetic complications [144].

Adipokines are bioactive substances produced by visceral adipose tissue. They balance pro-inflammatory and anti-inflammatory effects of adipose tissue [145]. DM contributes to adipose tissue dysfunction leading to insulin resistance, vascular injury, and consequent vascular disease. Several studies are exploring the possible role of adipokines as biomarkers for diabetic vascular complications. Our group found that omentin-1 serum levels were significantly lower in diabetic patients with PAD than in diabetic patients without PAD [146]. We also showed that the baseline omentin-1 levels were associated with MACE and MALE after LER in diabetic patients with PAD and CLTI [147]. Omentin-1 may help stratify patients to facilitate a more appropriate diagnostic and prognostic assessment.

Sortilin is a protein mainly expressed in hepatocytes implicated in LDL uptake by hepatocytes via an independent LDL-receptor mechanism and by macrophages in the process of foam cell formation in atheroma [148]. Moreover, sortilin plays a role in intracellular cytokine traffic and in platelet activation [149]. Several researchers have examined a possible association among sortilin, atherosclerosis, diabetes, and cardiovascular complications [150]. We observed that sortilin is independently associated in a diabetic population with PAD [151]. We recently showed that sortilin levels were related with MACE and MALE incidence after LER in a diabetic population with PAD and CLTI [152].

Further investigations on a larger cohort are required to confirm our results on the role of omentin-1 and sortilin. Currently, no biomarkers are available in clinical practice to predict LER failure in patients with CLTI. Biomarkers could allow risk stratification and an effective follow-up of these patients.

\section{The Rationale of Surveillance and Post-Procedural Care}

There is still no agreement on follow-up after EVT of CLTI at this time. The rationale of surveillance is to detect and treat revascularization failure before patency loss in order to implement preventive strategies for disease progression while avoiding other cardiovascular events [153]. Indeed, endpoints such as primary-assisted patency will depend on how these lesions are diagnosed and the specialist's persistency to treat them [7]. Nevertheless, high-quality evidence supporting systematic surveillance are still lacking [153]. The SVS suggests clinical examination, ankle brachial index (ABI), and duplex ultrasound imaging (DUS) within the first month following femoropopliteal artery EVT to provide a post-treatment baseline and evaluate for residual stenosis and continued surveillance at 3 months and then every 6 months [15,154-156]. 
GVG recommend that patients undergoing EVT for CLTI should maintain medical treatments to decelerate atherosclerosis progression and moderate the impact of risk factors [3]. Long-term antiplatelet therapy is pivotal to reduce atherothrombotic events and to improve patency and limb salvage rates after EVT $[157,158]$. Despite an absence of ascertained evidence, dual antiplatelet therapy (DAPT), aspirin plus clopidogrel, is often prescribed for 1 to 6 months after EVT $[159,160]$. Further clinical trials are needed to better understand the risks and benefits of DAPT after EVT and to define optimal dosage and treatment duration. No clear recommendation regarding the potential benefit of cilostazol after EVT for CLTI exist [3]. Clearly, lifestyle modifications should be optimized.

\section{Conclusions}

Patients affected by CLTI should be managed by a multidisciplinary team and with a comprehensive approach (Figure 1). Further clinical trials are required to validate and refine PLAN to assess patients' preoperative risk, limb severity, and anatomic disease patterns. In this review, we identified known factors or conditions for which effective therapeutic strategies do not exist yet. Increased awareness of these predictive conditions of restenosis may guide efforts to improve the assessment of patients with CLTI. All-encompassing tools are required to simplify therapeutic choices in the setting of a complex disease that always arises in patients with several comorbidities.

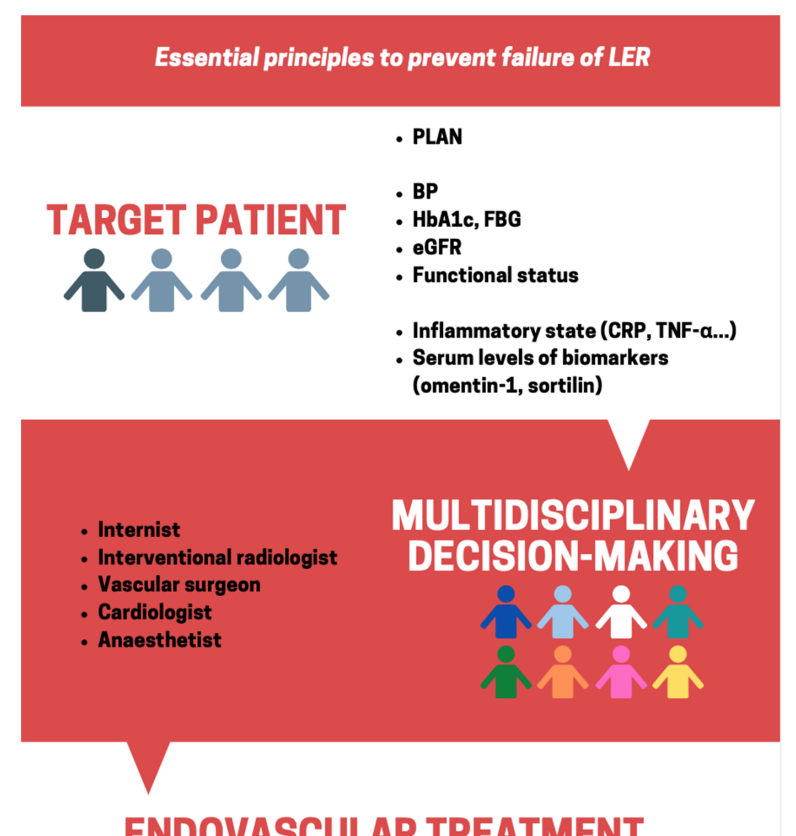

\section{ENDOVASCULAR TREATMENT}

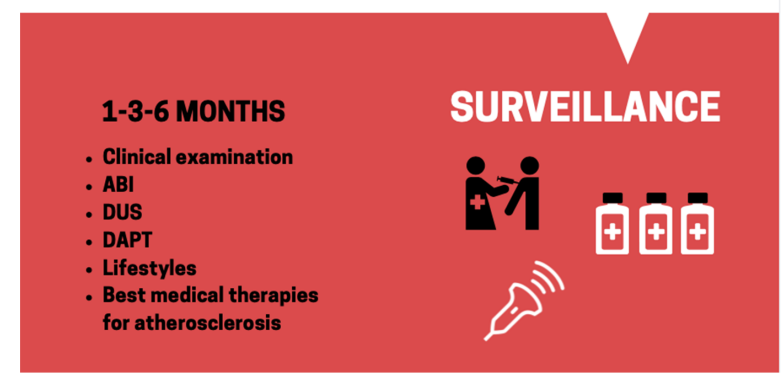

Figure 1. Essential principles to prevent failure of Lower extremity endovascular revascularization (LER). PLAN: Patient risk estimation, Limb severity, ANatomic disease patter; BP: blood pressure; $\mathrm{HbA1c}$ : glycated hemoglobin; FBG: fasting blood glucose; eGFR: estimated glomerular filtration rate; CRP: C-reactive protein; TNF- $\alpha$ : tumor necrosis factor- $\alpha$; ABI: ankle brachial index; DUS: duplex ultra sound; DAPT: dual antiplatelet therapy. 
Author Contributions: Conceptualization, F.B. and E.N.; methodology, F.B. and E.N.; resources, M.M.; data curation, A.F.; writing—original draft preparation, E.N.; writing-review and editing, E.N., M.M.R. and A.L.C.; supervision, A.G., M.M. and A.F. All authors have read and agreed to the published version of the manuscript.

Funding: This research received no external funding.

Institutional Review Board Statement: Not applicable.

Informed Consent Statement: Not applicable.

Acknowledgments: The authors are grateful to Franziska Lohmeyer for her English language assistance.

Conflicts of Interest: The authors declare no conflict of interest.

\section{References}

1. Fowkes, F.G.R.; Rudan, D.; Rudan, I.; Aboyans, V.O.; Denenberg, J.; McDermott, M.M.E.; Norman, P.A.; Sampson, U.K.; Williams, L.J.A.; Mensah, G.; et al. Comparison of Global Estimates of Prevalence and Risk Factors for Peripheral Artery Disease in 2000 and 2010: A Systematic Review and Analysis. Lancet 2013, 382, 1329-1340. [CrossRef]

2. Ouriel, K. Peripheral Arterial Disease. Lancet 2001, 358, 1257-1264. [CrossRef]

3. Conte, M.S.; Bradbury, A.W.; Kolh, P.; White, J.V.; Dick, F.; Fitridge, R.; Mills, J.L.; Ricco, J.B.; Suresh, K.R.; Murad, M.H.; et al. Global Vascular Guidelines on the Management of Chronic Limb-Threatening Ischemia. Eur. J. Vasc. Endovasc. Surg. 2019, 58, S1-S109.e133. [CrossRef] [PubMed]

4. Song, P.; Rudan, D.; Zhu, Y.I.; Fowkes, F.J.; Rahimi, K.; Fowkes, F.G.R.; Rudan, I. Global, Regional, and National Prevalence and Risk Factors for Peripheral Artery Disease in 2015: An Updated Systematic Review and Analysis. Lancet Glob. Health 2019, 7, e1020-e1030. [CrossRef]

5. Shu, J.; Santulli, G. Update on Peripheral Artery Disease: Epidemiology and Evidence-Based Facts. Atherosclerosis 2018, 275, 379-381. [CrossRef] [PubMed]

6. Malyar, N.; Fürstenberg, T.; Wellmann, J.; Meyborg, M.; Lüders, F.; Gebauer, K.; Bunzemeier, H.; Roeder, N.; Reinecke, H. Recent Trends in Morbidity and in-Hospital Outcomes of in-Patients with Peripheral Arterial Disease: A Nationwide Population-Based Analysis. Eur. Heart J. 2013, 34, 2706-2714. [CrossRef] [PubMed]

7. Owens, C.D.; Ho, K.J.; Conte, M.S. Risk Factors for Failure of Lower-Extremity Revascularization Procedures: Are They Different for Bypass and Percutaneous Procedures? Semin. Vasc. Surg. 2008, 21, 143-153. [CrossRef] [PubMed]

8. Adam, D.J.; Beard, J.D.; Cleveland, T.; Bell, J.; Bradbury, A.W.; Forbes, J.F.; Fowkes, F.G.R.; Gillepsie, I.; Ruckley, C.V.; Raab, G.; et al. Bypass versus Angioplasty in Severe Ischaemia of the Leg (BASIL): Multicentre, Randomised Controlled Trial. Lancet 2005, 366, 1925-1934. [CrossRef] [PubMed]

9. Brodmann, M.; Keirse, K.; Scheinert, D.; Spak, L.; Jaff, M.R.; Schmahl, R.; Li, P.; Zeller, T. Drug-Coated Balloon Treatment for Femoropopliteal Artery Disease. JACC Cardiovasc. Interv. 2017, 10, 2113-2123. [CrossRef]

10. Stavroulakis, K.; Borowski, M.; Torsello, G.; Bisdas, T.; Adili, F.; Balzer, K.; Billing, A.; Böckler, D.; Brixner, D.; Debus, E.S.; et al. One-Year Results of First-Line Treatment Strategies in Patients with Critical Limb Ischemia (CRITISCH Registry). J. Endovasc. Ther. 2018, 25, 320-329. [CrossRef]

11. Torsello, G.; Stavroulakis, K.; Brodmann, M.; Micari, A.; Tepe, G.; Veroux, P.; Benko, A.; Choi, D.; Vermassen, F.E.G.; Jaff, M.R.; et al. Three-Year Sustained Clinical Efficacy of Drug-Coated Balloon Angioplasty in a Real-World Femoropopliteal Cohort. J. Endovasc. Ther. 2020, 27, 693-705. [CrossRef] [PubMed]

12. Biscetti, F.; Ferraro, P.M.; Hiatt, W.R.; Angelini, F.; Nardella, E.; Cecchini, A.L.; Santoliquido, A.; Pitocco, D.; Landolfi, R.; Flex, A. Inflammatory Cytokines Associated with Failure of Lower-Extremity Endovascular Revascularization (LER): A Prospective Study of a Population with Diabetes. Diabetes Care 2019, 42, 1939-1945. [CrossRef] [PubMed]

13. Sacks, D.; Marinelli, D.L.; Martin, L.G.; Spies, J.B.; Committee SoIRTA. Reporting Standards for Clinical Evaluation of New Peripheral Arterial Revascularization Devices. J. Vasc. Interv. Radiol. 2003, 14, S395-S404. [CrossRef] [PubMed]

14. Rutherford, R.B.; Baker, J.; Ernst, C.; Johnston, K.; Porter, J.M.; Ahn, S.; Jones, D.N. Recommended Standards for Reports Dealing with Lower Extremity Ischemia: Revised Version. J. Vasc. Surg. 1997, 26, 517-538. [CrossRef]

15. Zierler, R.E.; Jordan, W.D.; Lal, B.K.; Mussa, F.; Leers, S.; Fulton, J.; Pevec, W.; Hill, A.; Murad, M.H. The Society for Vascular Surgery Practice Guidelines on Follow-up after Vascular Surgery Arterial Procedures. J. Vasc. Surg. 2018, 68, 256-284. [CrossRef] [PubMed]

16. Welt, F.G.; Rogers, C. Inflammation and Restenosis in the Stent Era. Arter. Thromb. Vasc. Biol. 2002, 22, 1769-1776. [CrossRef] [PubMed]

17. Nakatani, M.; Takeyama, Y.; Shibata, M.; Yorozuya, M.; Suzuki, H.; Koba, S.; Katagiri, T. Mechanisms of Restenosis after Coronary Intervention: Difference between Plain Old Balloon Angioplasty and Stenting. Cardiovasc. Pathol. 2003, 12, 40-48. [CrossRef]

18. Pasterkamp, G.; De Kleijn, D.P.; Borst, C. Arterial Remodeling in Atherosclerosis, Restenosis and after Alteration of Blood Flow: Potential Mechanisms and Clinical Implications. Cardiovasc. Res. 2000, 45, 843-852. [CrossRef] 
19. Herity, N.A.; Ward, M.R.; Lo, S.; Yeung, A.C. Review: Clinical Aspects of Vascular Remodeling. J. Cardiovasc. Electrophysiol. 1999, 10, 1016-1024. [CrossRef]

20. Post, M.J.; De Smet, B.J.G.L.; Van Der Helm, Y.; Borst, C.; Kuntz, R.E. Arterial Remodeling after Balloon Angioplasty or Stenting in an Atherosclerotic Experimental Model. Circulation 1997, 96, 996-1003. [CrossRef]

21. Mintz, G.S.; Popma, J.J.; Pichard, A.D.; Kent, K.M.; Satler, L.F.; Wong, C.; Hong, M.K.A.; Kovach, J.; Leon, M.B. Arterial Remodeling after Coronary Angioplasty: A Serial Intravascular Ultrasound Study. Circulation 1996, 94, 35-43. [CrossRef]

22. Post, M.J.; Borst, C.; Kuntz, R.E. The Relative Importance of Arterial Remodeling Compared with Intimal Hyperplasia in Lumen Renarrowing after Balloon Angioplasty. A Study in the Normal Rabbit and the Hypercholesterolemic Yucatan Micropig. Circulation 1994, 89, 2816-2821. [CrossRef] [PubMed]

23. Saraidaridis, J.T.; Patel, V.I.; Lancaster, R.T.; Cambria, R.P.; Conrad, M.F. Applicability of the Society for Vascular Surgery's Objective Performance Goals for Critical Limb Ischemia to Current Practice of Lower-Extremity Bypass. Ann. Vasc. Surg. 2016, 30, 59-65. [CrossRef] [PubMed]

24. Fashandi, A.Z.; Mehaffey, J.H.; Hawkins, R.B.; Kron, I.L.; Upchurch, G.R.; Robinson, W.P. Major Adverse Limb Events and Major Adverse Cardiac Events after Contemporary Lower Extremity Bypass and Infrainguinal Endovascular Intervention in Patients with Claudication. J. Vasc. Surg. 2018, 68, 1817-1823. [CrossRef] [PubMed]

25. Fleisher, L.A.; Fleischmann, K.E.; Auerbach, A.D.; Barnason, S.A.; Beckman, J.A.; Bozkurt, B. 2014 Acc/Aha Guideline on Perioperative Cardiovascular Evaluation and Management of Patients Undergoing Noncardiac Surgery: A Report of the American College of Cardiology/American Heart Association Task Force on Practice Guidelines. J. Am. Coll Cardiol. 2014, 64, 77-137. [CrossRef]

26. Kristensen, S.D.; Knuuti, J.; Saraste, A.; Anker, S.; Bøtker, H.E.; Hert, S.D. 2014 Esc/Esa Guidelines on Non-cardiac Surgery: Cardiovascular Assessment and Management: The Joint Task Force on Non-Cardiac Surgery: Cardiovascular Assessment and Management of the European Society of Cardiology (Esc) and the European Society of Anaesthesiology (Esa). Eur. Heart J. 2014, 35, 2383-2431. [PubMed]

27. Kraiss, L.W.; Beckstrom, J.L.; Brooke, B.S. Frailty Assessment in Vascular Surgery and Its Utility in Preoperative Decision Making. Semin. Vasc. Surg. 2015, 28, 141-147. [CrossRef] [PubMed]

28. Biancari, F.; Salenius, J.-P.; Heikkinen, M.; Luther, M.; Ylönen, K.; Lepäntalo, M. Risk-scoring Method for Prediction of 30-Day Postoperative Outcome after Infrainguinal Surgical Revascularization for Critical Lower-Limb Ischemia: A Finnvasc Registry Study. World J. Surg. 2007, 31, 217-225. [CrossRef]

29. Schanzer, A.; Mega, J.; Meadows, J.; Samson, R.H.; Bandyk, D.F.; Conte, M.S. Risk Stratification in Critical Limb Ischemia: Derivation and Validation of a Model to Predict Amputation-Free Survival Using Multicenter Surgical Outcomes Data. J. Vasc. Surg. 2008, 48, 1464-1471. [CrossRef] [PubMed]

30. Bradbury, A.W.; Adam, D.J.; Bell, J.; Forbes, J.F.; Fowkes, F.G.R.; Gillespie, I.; Ruckley, C.V.; Raab, G.M. Bypass versus Angioplasty in Severe Ischaemia of the Leg (BASIL) Trial: A Survival Prediction Model to Facilitate Clinical Deci-Sion Making. J. Vasc. Surg. 2010, 51, 52S-68S. [CrossRef]

31. Meltzer, A.J.; Graham, A.; Connolly, P.H.; Meltzer, E.C.; Karwowski, J.K.; Bush, H.L.; Schneider, D.B. The Comprehensive Risk Assessment for Bypass (CRAB) Facilitates Efficient Perioperative Risk Assessment for Patients with Critical Limb Ischemia. J. Vasc. Surg. 2013, 57, 1186-1195. [CrossRef] [PubMed]

32. Simons, J.P.; Goodney, P.P.; Flahive, J.; Hoel, A.W.; Hallett, J.W.; Kraiss, L.W.; Schanzer, A.; Initiative, S.F.V.S.V.Q. A Comparative Evaluation of Risk-Adjustment Models for Benchmarking Amputation-Free Survival after Lower Extremity Bypass. J. Vasc. Surg. 2016, 63, 990-997. [CrossRef] [PubMed]

33. Soga, Y.; Iida, O.; Takahaera, M.; Hirano, K.; Suzuki, K.; Kawasaki, D.; Miyashita, Y.; Tsuchiya, T. Two-Year Life Expectancy in Patients with Critical Limb Ischemia. JACC Cardiovasc. Interv. 2014, 7, 1444-1449. [CrossRef] [PubMed]

34. Taylor, S.M.; Kalbaugh, C.A.; Blackhurst, D.W.; Cass, A.L.; Trent, E.A.; Langan, E.M.; Youkey, J.R. Determinants of Functional Outcome after Revascularization for Critical Limb Ischemia: An Analysis of 1000 Consecutive Vascular Interventions. J. Vasc. Surg. 2006, 44, 747-756. [CrossRef]

35. Zhan, L.X.; Branco, B.C.; Armstrong, D.G.; Mills, J.L. The Society for Vascular Surgery Lower Extremity Threatened Limb Classification System Based on Wound, Ischemia, and Foot Infection (WIfI) Correlates with Risk of Major Amputation and Time to Wound Healing. J. Vasc. Surg. 2015, 61, 939-944. [CrossRef]

36. Robinson, W.P.; Loretz, L.; Hanesian, C.; Flahive, J.; Bostrom, J.; Lunig, N.; Schanzer, A.; Messina, L. Society for Vascular Surgery Wound, Ischemia, foot Infection (WIfI) Score Correlates with the Intensity of Multimodal Limb Treatment and PatientCentered Outcomes in Patients with Threatened Limbs Managed in a Limb Preservation Center. J. Vasc. Surg. 2017, 66, 488-498.e2. [CrossRef]

37. Mills, J.L.; Conte, M.S.; Armstrong, D.G.; Pomposelli, F.B.; Schanzer, A.; Sidawy, A.N.; Andros, G. The Society for Vascular Surgery Lower Extremity Threatened Limb Classification System: Risk Stratification based on Wound, Ischemia, and foot Infection (WIfI). J. Vasc. Surg. 2014, 59, 220-234.e2. [CrossRef] [PubMed]

38. Mills, J.L. Update and Validation of the Society for Vascular Surgery Wound, Ischemia, and Foot Infection Threatened Limb Classification System. Semin. Vasc. Surg. 2014, 27, 16-22. [CrossRef]

39. Cull, D.L.; Manos, G.; Hartley, M.C.; Taylor, S.M.; Langan, E.M.; Eidt, J.F.; Johnson, B.L. An early validation of the Society for Vascular Surgery Lower Extremity Threatened Limb Classification System. J. Vasc. Surg. 2014, 60, 1535-1542. [CrossRef] [PubMed] 
40. Darling, J.D.; McCallum, J.C.; Soden, P.A.; Guzman, R.; Raul, J.; Wyers, M.; Mark, C.; Hamdan, A.; Allen, D.; Verhagen, H.J.; et al. Predictive ability of the Society for Vascular Surgery Wound, Ischemia, and foot Infection (WIfI) Classification System after First-Time Lower Extremity Revascularizations. J. Vasc. Surg. 2017, 65, 695-704. [CrossRef]

41. Mayor, J.; Chung, J.; Zhang, Q.; Montero-Baker, M.; Schanzer, A.; Conte, M.S.; Mills, J.L. Using the Society for Vascular Surgery Wound, Ischemia, and Foot Infection Classification to Identify Patients Most Likely to Benefit from Revascularization. J. Vasc. Surg. 2019, 70, 776-785.e1. [CrossRef]

42. Jaff, M.R.; White, C.J.; Hiatt, W.R.; Fowkes, G.R.; Dormandy, J.; Razavi, M.; Reekers, J.; Norgren, L. An Update on Methods for Revascularization and Expansion of the Tasc Lesion Classification to Include below-the-Knee Arteries: A Supplement to the Inter-Society Consensus for the Management of Peripheral Arterial Disease (Tasc ii). J. Endovasc. Ther. 2015, $22,663-677$. [CrossRef] [PubMed]

43. Bollinger, A.; Breddin, K.; Hess, H.; Heystraten, F.; Kollath, J.; Konttila, A.; Pouliadis, G.; Marshall, M.; Mey, T.; Mietaschk, A.; et al. Semiquantitative Assessment of Lower Limb Atherosclerosis from Routine Angiographic Images. Atherosclerosis 1981, 38, 339-346. [CrossRef]

44. Kodama, A.; Meecham, L.; Popplewell, M.; Bate, G.; Conte, M.S.; Bradbury, A.W. Relationship between Global Anatomic Staging System (Glass) and Clinical Outcomes Following Revascularisation for Chronic Limb Threatening Ischaemia in the Bypass versus Angioplasty in Severe Ischaemia of the Leg (Basil)-1 Trial. Eur. J. Vasc. Endovasc. Surg. 2020, 60, 687-695. [CrossRef]

45. O'Donnell, T.F.; Deery, S.E.; Darling, J.D.; Shean, K.E.; Mittleman, M.A.; Yee, G.N.; Dernbach, M.R.; Schermerhorn, M.L. Adherence to Lipid Management Guidelines Is Associated with Lower Mortality and Major Adverse Limb Events in Patients Un-Dergoing Revascularization for Chronic Limb-Threatening Ischemia. J. Vasc. Surg. 2017, 66, 572-578. [CrossRef] [PubMed]

46. Bavry, A.A.; Anderson, R.D.; Gong, Y.; Denardo, S.J.; Cooper-Dehoff, R.M.; Handberg, E.M.; Pepine, C.J. Outcomes among Hypertensive Patients with Concomitant Peripheral and Coronary Artery Disease: Findings from the Interna-Tional VerapamilSR/Trandolapril Study. Hypertension 2010, 55, 48-53. [CrossRef]

47. Heart Outcomes Prevention Evaluation Study Investigators; Yusuf, S.; Sleight, P.; Pogue, J.; Bosch, J.; Davies, R.; Dagenais, G. Effects of an Angiotensin-Converting-Enzyme Inhibitor, Ramipril, on Cardiovascular Events in High-Risk Patients. N. Engl. J. Med. 2000, 342, 145-153. [CrossRef]

48. Sleight, P. The HOPE Study (Heart Outcomes Prevention Evaluation). J. Renin-Angiotensin-Aldosterone Syst. 2000, 1, 18-20. [CrossRef] [PubMed]

49. Armstrong, E.J.; Chen, D.C.; Singh, G.D.A.; Amsterdam, E.; Laird, J.R. Angiotensin-Converting Enzyme Inhibitor or Angiotensin Receptor Blocker Use Is Associated with Reduced Major Adverse Cardiovascular Events among Patients with Critical Limb Ischemia. Vasc. Med. 2015, 20, 237-244. [CrossRef]

50. Kray, E.J.; Dombrovskiy, V.Y.; Vogel, T.R. Use of Angiotensin-Converting Enzyme Inhibitors and Freedom from Amputation after Lower Extremity Revascularization. Vasc. Health Risk Manag. 2017, 13, 269-274. [CrossRef]

51. Høgh, A.; Lindholt, J.S.; Nielsen, H.; Jensen, L.P.; Johnsen, S.P. Use of Angiotensin-Converting Enzyme Inhibitors and Cardiovascular Outcomes Following Primary Vascular Surgery: A Nation-Wide Propensity Score Matched Follow-Up Study. Vasc Endovasc. Surg. 2012, 46, 515-523. [CrossRef]

52. Khan, S.Z.; Montross, B.; Rivero, M.; Cherr, G.S.; Harris, L.M.; Dryjski, M.L.; Dosluoglu, H.H. Angiotensin Converting Enzyme Inhibitors and Angiotensin II Receptor Blockers (ACEI/ARB) are Associated with Improved Limb Salvage after Infrapopliteal Interventions for Critical Limb Ischemia. Ann. Vasc. Surg. 2020, 63, 275-286. [CrossRef] [PubMed]

53. Roberts, D.H.; Tsao, Y.A.; McLoughlin, G.; Breckenridge, A. Placebo-Controlled Comparison of Captopril, Atenolol, Labetalol, and Pindolol in Hypertension Complicated by Intermittent Claudication. Lancet 1987, 2, 650-653. [CrossRef]

54. Lepantalo, M. Chronic Effects of Metoprolol and Methyldopa on Calf Blood Flow in Intermittent Claudication. Br. J. Clin. Pharmacol. 1984, 18, 90-93. [CrossRef] [PubMed]

55. Paravastu, S.C.; Mendonca, D.A.; Da Silva, A. Beta Blockers for Peripheral Arterial Disease. Cochrane Database Syst Rev. 2013, CD005508. [CrossRef] [PubMed]

56. Manapurathe, T.D.; Krishna, S.M.; Dewdney, B.; Moxon, J.V.; Biros, E.; Golledge, J. Effect of Blood Pressure Lowering Medications on Leg Ischemia in Peripheral Artery Disease Patients: A Meta-Analysis of Ran-Domised Controlled Trials. PLoS ONE 2017, 12, e0178713. [CrossRef]

57. Vrsalovic, M. Diabetes and Peripheral Artery Disease: A Bad Combination. Am. J. Surg. 2018, 216, 182-183. [CrossRef] [PubMed]

58. Britton, K.A.; Mukamal, K.J.; Ix, J.H.; Siscovick, D.S.; Newman, A.B.; De Boer, I.H.; Thacker, E.L.; Biggs, M.L.; Gaziano, J.M.; Djoussé, L. Insulin Resistance and Incident Peripheral Artery Disease in the Cardiovascular Health Study. Vasc. Med. 2012, 17, 85-93. [CrossRef]

59. Joosten, M.M.; Pai, J.K.; Bertoia, M.L.; Rimm, E.B.; Spiegelman, D.; Mittleman, M.A.; Mukamal, K.J. Associations Between Conventional Cardiovascular Risk Factors and Risk of Peripheral Artery Disease in Men. JAMA 2012, 308, 1660-1667. [CrossRef]

60. Collaboration PSCaAPCS. SEx-specific Relevance of Diabetes to Occlusive Vascular and Other Mortality: A Collaborative Meta-Analysis of Individual Data from 980793 Adults from 68 Prospective Studies. Lancet Diabetes Endocrinol. 2018, 6, 538-546. [CrossRef]

61. Domingueti, C.P.; Dusse, L.M.S.; Carvalho, M.D.G.; De Sousa, L.P.; Gomes, K.B.; Fernandes, A.P. Diabetes Mellitus: The Linkage between Oxidative Stress, Inflammation, Hypercoagulability and Vascular Complications. J. Diabetes Complicat. 2016, 30, 738-745. [CrossRef] 
62. Vrsalovic, M.; Vucur, K.; Presecki, A.V.; Fabijanic, D.; Milosevic, M. Impact of Diabetes on Mortality in Peripheral Artery Disease: A Meta-Analysis. Clin. Cardiol. 2017, 40, 287-291. [CrossRef]

63. Haltmayer, M.; Mueller, T.; Horvath, W.; Luft, C.; Poelz, W.; Haidinger, D. Impact of Atherosclerotic Risk Factors on the Anatomical Distribution of Peripheral Arterial Disease. Int. Angiol. 2001, 20, 200-207.

64. Thiruvoipati, T.; Kielhorn, C.E.; Armstrong, E.J. Peripheral Artery Disease in Patients with Diabetes: Epidemiology, Mechanisms, and Outcomes. World J. Diabetes 2015, 6, 961-969. [CrossRef] [PubMed]

65. Jude, E.B.; Oyibo, S.O.; Chalmers, N.; Boulton, A.J. Peripheral Arterial Disease in Diabetic and Nondiabetic Patients: A Comparison of Severity and Outcome. Diabetes Care 2001, 24, 1433-1437. [CrossRef]

66. Arya, S.; Binney, Z.O.; Khakharia, A.; Long, C.A.; Brewster, L.P.; Wilson, P.W.; Rajani, R.R.; Goodney, P.P.; Jordan, W.D. High Hemoglobin A. J. Vasc. Surg. 2018, 67, 217-228.e211. [CrossRef]

67. Fowkes, F.G.R.; Aboyans, V.; McDermott, M.M.; Sampson, U.K.A.; Criqui, M.H. Peripheral Artery Disease: Epidemiology and Global Perspectives. Nat. Rev. Cardiol. 2017, 14, 156-170. [CrossRef] [PubMed]

68. Kallio, M.; Forsblom, C.; Groop, P.-H.; Groop, L.; Lepäntalo, M. Development of New Peripheral Arterial Occlusive Disease in Patients with Type 2 Diabetes during a Mean Follow-up of 11 Years. Diabetes Care 2003, 26, 1241-1245. [CrossRef]

69. Conte, M.S.; Pomposelli, F.B.; Clair, D.G.; Geraghty, P.J.; McKinsey, J.F.; Mills, J.L.; Moneta, G.L.; Murad, M.H.; Powell, R.J.; Reed, A.B.; et al. Society for Vascular Surgery Practice Guidelines for Atherosclerotic Occlusive Disease of the Lower Extremities: Management of Asymptomatic Disease and Claudication. J. Vasc. Surg. 2015, 61, 2S-41S.e1. [CrossRef]

70. Hingorani, A.; LaMuraglia, G.M.; Henke, P.; Meissner, M.H.; Loretz, L.; Zinszer, K.M.; Driver, V.R.; Frykberg, R.; Carman, T.L.; Marston, W.; et al. The Management of Diabetic Foot: A Clinical Practice Guideline by the Society for Vascular Surgery in Collaboration with the American Podiatric Medical Association and the Society for Vascular Medicine. J. Vasc. Surg. 2016, 63, 3S-21S. [CrossRef] [PubMed]

71. Selvin, E.; Marinopoulos, S.; Berkenblit, G.; Rami, T.; Brancati, F.L.; Powe, N.R.; Golden, S.H. Meta-Analysis: Glycosylated Hemoglobin and Cardiovascular Disease in Diabetes Mellitus. Ann. Intern. Med. 2004, 141, 421-431. [CrossRef]

72. Gerstein, H.C.E.; Miller, M.; Byington, R.P.; Goff, D.C.; Bigger, J.T.; Buse, J.B.; Cushman, W.C.; Genuth, S.; Ismail-Beigi, F.; Grimm, R.H.; et al. Effects of Intensive Glucose Lowering in Type 2 Diabetes. N. Engl. J. Med. 2008, 358, 2545-2559. [CrossRef] [PubMed]

73. Patel, A.; MacMahon, S.; Chalmers, J.; Neal, B.; Billot, L.; Joshi, R.; Woodward, M.; Marre, M.; Travert, F.; Cooper, M.; et al. Intensive Blood Glucose Control and Vascular Outcomes in Patients with Type 2 Diabetes. N. Engl. J. Med. 2008, 358, 2560-2572. [CrossRef]

74. Duckworth, W.; Abraira, C.; Moritz, T.; Reda, D.; Emanuele, N.; Reaven, P.D.; Zieve, F.J.; Marks, J.; Davis, S.N.; Hayward, R.; et al. Glucose Control and Vascular Complications in Veterans with Type 2 Diabetes. N. Engl. J. Med. 2009, 360, 129-139. [CrossRef] [PubMed]

75. Cavender, M.A.; Scirica, B.M.; Raz, I.; Steg, P.G.; McGuire, D.K.; Leiter, L.A.; Hirshberg, B.; Davidson, J.; Cahn, A.; Mosenzon, O.; et al. Cardiovascular Outcomes of Patients in SAVOR-TIMI 53 by Baseline Hemoglobin A1c. Am. J. Med. 2016, 129, 340.e1-340.e8. [CrossRef] [PubMed]

76. Wang, L.C.C.; Blomster, J.I.; Heizer, G.; Berger, J.S.; Baumgartner, I.; Fowkes, F.G.R.; Held, P.; Katona, B.G.; Norgren, L.; Jones, W.S. Cardiovascular and Limb Outcomes in Patients with Diabetes and Peripheral Artery Disease: The Euclid Trial. J. Am. Coll. Cardiol. 2018, 72, 3274-3284. [CrossRef]

77. Goldman, M.P.; Clark, C.J.; Craven, T.E.; Davis, R.P.; Williams, T.K.; Velazquez-Ramirez, G.; Hurie, J.B.; Edwards, M.S. Effect of Intensive Glycemic Control on Risk of Lower Extremity Amputation. J. Am. Coll. Surg. 2018, 227, 596-604. [CrossRef]

78. Takahara, M.; Kaneto, H.; Iida, O.; Gorogawa, S.-I.; Katakami, N.; Matsuoka, T.-A.; Ikeda, M.; Shimomura, I. The Influence of Glycemic Control on the Prognosis of Japanese Patients Undergoing Percutaneous Transluminal Angioplasty for Critical Limb Ischemia. Diabetes Care 2010, 33, 2538-2542. [CrossRef] [PubMed]

79. Singh, S.; Armstrong, E.J.; Sherif, W.; Alvandi, B.; Westin, G.G.; Singh, G.D.A.; Amsterdam, E.; Laird, J.R. Association of Elevated Fasting Glucose with Lower Patency and Increased Major Adverse Limb Events among Patients with DI-Abetes Undergoing Infrapopliteal Balloon Angioplasty. Vasc. Med. 2014, 19, 307-314. [CrossRef]

80. Cha, J.-J.; Kim, H.; Ko, Y.-G.; Choi, D.; Lee, J.-H.; Yoon, C.-H.; Chae, I.-H.; Yu, C.W.; Lee, S.W.; Lee, S.-R.; et al. Influence of Preprocedural Glycemic Control on Clinical Outcomes of Endovascular Therapy in Diabetic Patients with Lower Ex-tremity Artery Disease: An Analysis from a Korean Multicenter Retrospective Registry Cohort. Cardiovasc. Diabetol. 2020, 19, 1-10. [CrossRef]

81. Singh, N.; Zeng, C.; Lewinger, J.P.; Wolfson, A.M.; Shavelle, D.; Weaver, F.; Garg, P.K. Preoperative Hemoglobin A1c Levels and Increased Risk of Adverse Limb Events in Diabetic Patients Undergoing Infrainguinal Lower Extremity Bypass Surgery in the Vascular Quality Initiative. J. Vasc. Surg. 2019, 70, 1225-1234.e1. [CrossRef] [PubMed]

82. Biscetti, F.; Pitocco, D.; Straface, G.; Zaccardi, F.; De Cristofaro, R.; Rizzo, P.; Lancellotti, S.; Arena, V.; Stigliano, E.; Musella, T.; et al. Glycaemic Variability Affects Ischaemia-Induced Angiogenesis in Diabetic Mice. Clin. Sci. 2011, 121, 555-564. [CrossRef]

83. Gorst, C.; Kwok, C.S.; Aslam, S.; Buchan, I.; Kontopantelis, E.; Myint, P.K.; Heatlie, G.; Loke, Y.; Rutter, M.K.; Mammas, M.A. Long-Term Glycemic Variabilityand Risk of Adverse Outcomes: A Systematic Review and Meta-Analysis. Diabetes Care 2015, 38, 2354-2369. [CrossRef]

84. Yang, C.-P.; Lin, C.-C.; Li, C.-I.; Liu, C.-S.; Lin, C.-H.; Hwang, K.-L.; Yang, S.-Y.; Li, T.-C. Fasting Plasma Glucose Variability and $\mathrm{HbA1c}$ Are Associated with Peripheral Artery Disease Risk in Type 2 Diabetes. Cardiovasc. Diabetol. 2020, 19, 1-13. [CrossRef] 
85. Brooke, B.S.; Kraiss, L.W.; Stone, D.H.; Nolan, B.; De Martino, R.R.; Reiber, G.E.; Goodman, D.C.; Cronenwett, J.L.; Goodney, P.P. Improving Outcomes for Diabetic Patients Undergoing Revascularization for Critical Limb Ischemia: Does the Quality of Outpatient Diabetic Care Matter? Ann. Vasc. Surg. 2014, 28, 1719-1728. [CrossRef] [PubMed]

86. Das, S.R.; Everett, B.M.; Birtcher, K.K.; Brown, J.M.; Cefalu, W.T.; Januzzi, J.L.; Kalyani, R.R.; Kosiborod, M.; Magwire, M.L.; Morris, P.B.; et al. 2018 ACC Expert Consensus Decision Pathway on Novel Therapies for Cardiovascular Risk Reduction in Patients with Type 2 Diabetes and Atherosclerotic Cardiovascular Disease: A Report of the American College of Cardiology Task Force on Expert Consensus Decision Pathways. J. Am. Coll. Cardiol. 2018, 72, 3200-3223. [PubMed]

87. Neal, B.; Perkovic, V.; Mahaffey, K.W.; De Zeeuw, D.; Fulcher, G.; Erondu, N.; Shaw, W.; Law, G.; Desai, M.; Matthews, D.R. Canagliflozin and Cardiovascular and Renal Events in Type 2 Diabetes. N. Engl. J. Med. 2017, 377, 644-657. [CrossRef] [PubMed]

88. Chatterjee, S.; Bandyopadhyay, D.; Ghosh, R.K.; Majumdar, U.; Aneja, A.; Lavie, C.J.; Deedwania, P. SGLT-2 Inhibitors and Peripheral Artery Disease: A Statistical Hoax or Reality? Curr. Probl. Cardiol. 2019, 44, 207-222. [CrossRef]

89. Li, D.; Yang, J.Y.; Wang, T.; Shen, S.; Tang, H. Risks of Diabetic Foot Syndrome and Amputation Associated with Sodium Glucose Co-transporter 2 Inhibitors: A Meta-Analysis of Randomized Controlled Trials. Diabetes Metab. 2018, 44, 410-414. [CrossRef]

90. Potier, L.; Roussel, R.; Velho, G.; Saulnier, P.-J.; Bumbu, A.; Matar, O.; Schneider, F.; Ragot, S.; Marre, M.; Mohammedi, K.; et al. Lower Limb Events in Individuals with Type 2 Diabetes: Evidence for an Increased Risk Associated with Diuretic Use. Diabetology 2019, 62, 939-947. [CrossRef]

91. Xie, W.; Song, X.; Liu, Z. Impact of Dipeptidyl-Peptidase 4 Inhibitors on Cardiovascular Diseases. Vasc. Pharmacol. 2018, 109, 17-26. [CrossRef]

92. O'Hare, A.M.; Vittinghoff, E.; Hsia, J.; Shlipak, M.G. Renal Insufficiency and the Risk of Lower Extremity Peripheral Arterial Disease: Results from the Heart and Estrogen/Progestin Replacement Study (HERS). J. Am. Soc. Nephrol. 2004, 15, 1046-1051. [CrossRef] [PubMed]

93. Lacroix, P.; Aboyans, V.; Desormais, I.; Kowalsky, T.; Cambou, J.P.; Constans, J.; Rivière, A.B. Chronic Kidney Disease and the Short-Term Risk of Mortality and Amputation in Patients Hospitalized for Peripheral Artery Disease. J. Vasc. Surg. 2013, 58, 966-971. [CrossRef] [PubMed]

94. Harfouch, B.; Prasad, A. Implications of Renal Disease in Patients Undergoing Peripheral Arterial Interventions. Interv. Cardiol. Clin. 2020, 9, 345-356. [CrossRef] [PubMed]

95. O'Hare, A.M.; Glidden, D.V.; Fox, C.S.; Hsu, C.Y. High Prevalence of Peripheral Arterial Disease in Persons with Renal Insufficiency: Results from the National Health and Nutri-Tion Examination Survey 1999-2000. Circulation 2004, 109, 320-323. [CrossRef]

96. Rajagopalan, S.; Dellegrottaglie, S.; Furniss, A.L.; Gillespie, B.W.; Satayathum, S.; Lameire, N.; Saito, A.; Akiba, T.; Jadoul, M.; Ginsberg, N.; et al. Peripheral Arterial Disease in Patients with End-Stage Renal Disease: Observations from the Dialysis Outcomes and Practice Pat-Terns Study (Dopps). Circulation 2006, 114, 1914-1922. [CrossRef]

97. O'Hare, A.; Johansen, K. Lower-Extremity Peripheral Arterial Disease among Patients with End-Stage Renal Disease. J. Am. Soc. Nephrol. 2001, 12, 2838-2847.

98. Herzog, C.A.; Asinger, R.W.; Berger, A.K.; Charytan, D.M.; Diez, J.D.M.; Hart, R.G.; Eckardt, K.-U.; Kasiske, B.L.; McCullough, P.A.; Passman, R.S.; et al. Cardiovascular Disease in Chronic Kidney Disease. a Clinical Update from Kidney Disease: Improving Global Outcomes (KDIGO). Kidney Int. 2011, 80, 572-586. [CrossRef]

99. Workgroup, K. K/DOQI Clinical Practice Guidelines for Cardiovascular Disease in Dialysis Patients. Am. J. Kidney Dis. 2005, $45, \mathrm{~S} 1-\mathrm{S} 153$.

100. Kolte, D.; Kennedy, K.; Shishehbor, M.; Abbott, J.; Khera, S.; Soukas, P. Thirty-Day Readmissions After Endovascular or Surgical Therapy for Critical Limb Ischemia: Analysis of the 2013 to 2014 Nationwide Readmissions Databases. J. Vasc. Surg. 2017, 66, 1911. [CrossRef]

101. Gerhard-Herman, M.D.; Gornik, H.L.; Barrett, C.; Barshes, N.R.; Corriere, M.A.; Drachman, D.E.; Rowkes, F.G.R.; Hamburg, N.M.; Kinlay, S.; Lookstein, R.; et al. 2016 Aha/Acc Guideline on the Management of Patients with Lower Extremity Peripheral Artery Disease: A Report of the American College of Cardiology/American Heart Association Task Force on Clinical Practice Guidelines. Circulation 2017, 135, e726-e779. [PubMed]

102. Smilowitz, N.R.; Bhandari, N.; Berger, J.S. Chronic Kidney Disease and Outcomes of Lower Extremity Revascularization for Peripheral Artery Disease. Atherosclerosis 2020, 297, 149-156. [CrossRef] [PubMed]

103. Wang, H.E.; Gamboa, C.; Warnock, D.G.; Muntner, P. Chronic Kidney Disease and Risk of Death from Infection. Am. J. Nephrol. 2011, 34, 330-336. [CrossRef] [PubMed]

104. Ašćerić, R.R.; Dimković, N.B.; Trajković, G.; Ristić, B.S.; Janković, A.N.; Durić, P.S.; Ilijevski, N.S. Prevalence, Clinical Characteristics, and Predictors of Peripheral Arterial Disease in Hemodialysis Patients: A Cross-Sectional Study. BMC Nephrol. 2019, $20,281$. [CrossRef] [PubMed]

105. Arinze, N.V.; Gregory, A.; Francis, J.M.; Farber, A.; Chitalia, V.C. Unique Aspects of Peripheral Artery Disease in Patients with Chronic Kidney Disease. Vasc. Med. 2019, 24, 251-260. [CrossRef]

106. Okamoto, S.; Iida, O.; Mano, T. Current Perspective on Hemodialysis Patients with Peripheral Artery Disease. Ann. Vasc. Dis. 2017, 10, 88-91. [CrossRef]

107. Patel, V.I.; Mukhopadhyay, S.; Guest, J.M.; Conrad, M.F.; Watkins, M.T.; Kwolek, C.J.; LaMuraglia, G.M.; Cambria, R.P. Impact of Severe Chronic Kidney Disease on Outcomes of Infrainguinal Peripheral Arterial Intervention. J. Vasc. Surg. 2014, 59, 368-375. [CrossRef] 
108. Kim, H.O.; Kim, J.-M.; Woo, J.S.; Choi, D.; Ahn, C.-M.; Lee, S.-W.; Lee, J.-H.; Choi, S.-H.; Yu, C.W.; Min, P.K. Young-Guk other The Korean Vascular Intervention Society (K-VIS) Endovascular therapy in Lower Limb Artery diseases registry (ELLA) Registry Investigators; Effects of Chronic Kidney Disease on Clinical Outcomes in Patients with Peripheral Artery Disease Under-going Endovascular Treatment: Analysis from the K-VISELLA Registry. Int. J. Cardiol. 2018, 262, 32-37. [CrossRef]

109. O'Hare, A.M.; Bertenthal, D.; Shlipak, M.G.; Sen, S.; Chren, M.-M. Impact of Renal Insufficiency on Mortality in Advanced Lower Extremity Peripheral Arterial Disease. J. Am. Soc. Nephrol. 2004, 16, 514-519. [CrossRef]

110. Lüders, F.; Bunzemeier, H.; Engelbertz, C.; Malyar, N.M.; Meyborg, M.; Roeder, N.; Berger, K.; Reinecke, H. CKD and Acute and Long-Term Outcome of Patients with Peripheral Artery Disease and Critical Limb Ischemia. Clin. J. Am. Soc. Nephrol. 2015, 11, 216-222. [CrossRef]

111. Heideman, P.P.; Rajebi, M.R.; McKusick, M.A.; Bjarnason, H.; Oderich, G.S.; Friese, J.L.; Fleming, M.D.; Stockland, A.H.; Harmsen, W.S.; Mandrekar, J.; et al. Impact of Chronic Kidney Disease on Clinical Outcomes of Endovascular Treatment for Femoropopliteal Arterial Disease. J. Vasc. Interv. Radiol. 2016, 27, 1204-1214. [CrossRef] [PubMed]

112. Ortmann, J.; Gahl, B.; Diehm, N.; Dick, F.; Traupe, T.; Baumgartner, I. Survival Benefits of Revascularization in Patients with Critical Limb Ischemia and Renal Insufficiency. J. Vasc. Surg. 2012, 56, 737-745.e1. [CrossRef] [PubMed]

113. Fallon, J.M.; Goodney, P.P.; Stone, D.H.; Patel, V.I.; Nolan, B.W.; Kalish, J.A.; Zhao, Y.; Hamdan, A.D. Vascular Study Group of New England Outcomes of Lower Extremity Revascularization among the Hemodialysis-Dependent. J. Vasc. Surg. 2015, 62, 1183-1191.e1. [CrossRef] [PubMed]

114. Xie, J.X.; Glorioso, T.J.; Dattilo, P.B.; Aggarwal, V.; Ho, P.M.; Barón, A.E.; Donaldson, D.; Armstrong, E.J.; Klein, A.; Giri, J.; et al. Effect of Chronic Kidney Disease on Mortality in Patients Who Underwent Lower Extremity Peripheral Vascular Intervention. Am. J. Cardiol. 2017, 119, 669-674. [CrossRef] [PubMed]

115. Meyer, A.; Schinz, K.; Lang, W.; Schmid, A.; Regus, S.; Rother, U. Outcomes and Influence of the Pedal Arch in Below-the-Knee Angioplasty in Patients with End-Stage Renal Disease and Critical Limb Ischemia. Ann. Vasc. Surg. 2016, 35, 121-129. [CrossRef]

116. Nishibe, T.; Kondo, Y.; Dardik, A.; Muto, A.; Koizumi, J.; Nishibe, M. Stent Placement in the Superficial Femoral Artery for Patients on Chronic Hemodialysis with Peripheral Artery Disease. Int. Angiol. 2009, 28, 484-489.

117. Meyer, A.; Lang, W.; Borowski, M.; Torsello, G.; Bisdas, T.; Schmitz-Rixen, T.; Gkremoutis, A.; Steinbauer, M.; Betz, T.; Eckstein, H.-H.; et al. In-Hospital Outcomes in Patients with Critical Limb Ischemia and End-Stage Renal Disease after Revascularization. J. Vasc. Surg. 2016, 63, 966-973. [CrossRef]

118. Garimella, P.S.; Balakrishnan, P.; Correa, A.; Poojary, P.; Annapureddy, N.; Chauhan, K.; Patel, A.; Patel, S.; Konstantinidis, I.; Chan, L.; et al. Nationwide Trends in Hospital Outcomes and Utilization After Lower Limb Revascularization in Patients on Hemodialysis. JACC Cardiovasc. Interv. 2017, 10, 2101-2110. [CrossRef]

119. Khan, T.; Plotkin, A.; Magee, G.A.; Shin, L.; Woelfel, S.L.; Ziegler, K.R.; Shih, C.D.; Weaver, F.A.; Armstrong, D.G.; Rowe, V.L. Functional Ambulatory Status as a Potential Adjunctive Decision-Making Tool Following Wound, Level of Ischemia, and Severity of Foot Infection Assessment. J. Vasc. Surg. 2020, 72, 738-746. [CrossRef]

120. Mills, J.L. Modern Treatment of Chronic Limb-Threatening Ischemia Requires a Plan, Clinical Judgment, and Shared Decision Making. J. Vasc. Surg. 2020, 72, 389-390. [CrossRef]

121. Cesari, M.; Penninx, B.W.; Newman, A.B.; Kritchevsky, S.B.; Nicklas, B.J.; Sutton-Tyrrell, K. Inflammatory Markers and Onset of Cardiovascular Events: Results from the Health ABC Study. Circulation 2003, 108, 2317-2322. [CrossRef]

122. Burger-Kentischer, A.; Goebel, H.; Seiler, R.; Fraedrich, G.; Schaefer, H.E.; Dimmeler, S.; Kleemann, R.; Bernhagen, J.; Ihling, C. Expression of Macrophage Migration Inhibitory Factor in Different Stages of Human Atherosclerosis. Circulation 2002, 105, 1561-1566. [CrossRef] [PubMed]

123. Biscetti, F.; Straface, G.; Bertoletti, G.; Vincenzoni, C.; Snider, F.; Arena, V.; Landolfi, R.; Flex, A. Identification of a Potential Proinflammatory Genetic Profile Influencing Carotid Plaque Vulnerability. J. Vasc. Surg. 2015, 61, 374-381. [CrossRef] [PubMed]

124. Schmidt, M.I.; Duncan, B.B.; Sharrett, A.R.; Lindberg, G.; Savage, P.J.; Offenbacher, S.; Azambuja, M.I.; Tracy, R.P.; Heiss, G. Markers of Inflammation and Prediction of Diabetes Mellitus in Adults (Atherosclerosis Risk in Communities Study): A Cohort Study. Lancet 1999, 353, 1649-1652. [CrossRef]

125. Signorelli, S.S.; Katsiki, N. Oxidative Stress and Inflammation: Their Role in the Pathogenesis of Peripheral Artery Disease with or without Type 2 Diabetes Mellitus. Curr. Vasc. Pharmacol. 2018, 16, 547-554. [CrossRef]

126. Signorelli, S.S.; Anzaldi, M.; Libra, M.; Navolanic, P.M.; Malaponte, G.; Mangano, K.; Quattrocchi, C.; Marco, D.R.; Fiore, V.; Neri, S. Plasma Levels of Inflammatory Biomarkers in Peripheral Arterial Disease: Results of a Cohort Study. Angiology 2016, 67, 870-874. [CrossRef]

127. Unlu, Y.; Karapolat, S.; Karaca, Y.; Kiziltunc, A.; Kızıltunç, A. Comparison of Levels of Inflammatory Markers and Hemostatic Factors in the Patients with and without Peripheral Arterial Disease. Thromb. Res. 2006, 117, 357-364. [CrossRef]

128. Barani, J.; Nilsson, J.-A.; Mattiasson, I.; Lindblad, B.; Gottsäter, A. Inflammatory Mediators Are Associated with 1-Year Mortality in Critical Limb Ischemia. J. Vasc. Surg. 2005, 42, 75-80. [CrossRef] [PubMed]

129. Schillinger, M.; Exner, M.; Mlekusch, W.; Haumer, M.; Rumpold, H.; Ahmadi, R.; Sabeti, S.; Wagner, O.; Minar, E. Endovascular Revascularization Below the Knee: 6-month Results and Predictive Value of C-reactive Protein Level. Radiology 2003, 227, 419-425. [CrossRef] 
130. Lin, C.-W.; Hsu, L.-A.; Chen, C.-C.; Yeh, J.-T.; Sun, J.-H.; Lin, C.-H.; Chen, S.-T.; Hsu, B.R.-S.; Huang, Y.-Y. C-Reactive Protein as an Outcome Predictor for Percutaneous Transluminal Angioplasty in Diabetic Patients with Peripheral Arterial Disease and Infected Foot Ulcers. Diabetes Res. Clin. Pr. 2010, 90, 167-172. [CrossRef]

131. Bleda, S.; De Haro, J.; Acin, F.; Varela, C.; Esparza, L.; De Maturana, I.L. Inflammatory Burden Predicts Long-Term Outcomes in Endovascular Therapy in Peripheral Arterial Disease. Ann. Vasc. Surg. 2013, 27, 459-466. [CrossRef] [PubMed]

132. Stone, P.A.; Schlarb, H.; Campbell, J.E.; Williams, D.; Thompson, S.N.; John, M.; Campbell, J.R.; Aburahma, A.F. C-Reactive Protein and Brain Natriuretic Peptide as Predictors of Adverse Events after Lower Extremity Endovascular Revascularization. J. Vasc. Surg. 2014, 60, 652-660. [CrossRef] [PubMed]

133. Straface, G.; Biscetti, F.; Pitocco, D.; Bertoletti, G.; Misuraca, M.; Vincenzoni, C.; Snider, F.; Arena, V.; Stigliano, E.; Angelini, F.; et al. Assessment of the Genetic Effects of Polymorphisms in the Osteoprotegerin Gene, TNFRSF11B, on Serum Osteoprotegerin Levels and Carotid Plaque Vulnerability. Stroke 2011, 42, 3022-3028. [CrossRef] [PubMed]

134. Augoulea, A.; Vrachnis, N.; Lambrinoudaki, I.; Dafopoulos, K.; Iliodromiti, Z.; Daniilidis, A.; Varras, M.; Alexandrou, A.; Deligeoroglou, E.; Creatsas, G. Osteoprotegerin as a Marker of Atherosclerosis in Diabetic Patients. Int. J. Endocrinol. 2013, 2013, 1-6. [CrossRef] [PubMed]

135. Biscetti, F.; Porreca, C.F.; Bertucci, F.; Straface, G.; Santoliquido, A.; Tondi, P.; Angelini, F.; Pitocco, D.; Santoro, L.; Gasbarrini, A.; et al. TNFRSF11B Gene Polymorphisms Increased Risk of Peripheral Arterial Occlusive Disease and Critical Limb Ischemia in Patients with Type 2 Diabetes. Acta Diabetol. 2014, 51, 1025-1032. [CrossRef] [PubMed]

136. Giovannini, S.; Tinelli, G.; Biscetti, F.; Straface, G.; Angelini, F.; Pitocco, D.; Mucci, L.; Landolfi, R.; Flex, A. Serum High Mobility Group Box-1 and Osteoprotegerin Levels Are Associated with Peripheral Arterial Disease and Critical Limb Ischemia in Type 2 Diabetic Subjects. Cardiovasc. Diabetol. 2017, 16, 1-9. [CrossRef]

137. Protogerou, A.; Zampeli, E.; Fragiadaki, K.; Stamatelopoulos, K.; Papamichael, C.; Sfikakis, P. A Pilot Study of Endothelial Dysfunction and Aortic Stiffness after Interleukin-6 Receptor Inhibition in Rheumatoid Arthritis. Atherosclerosis 2011, 219, 734-736. [CrossRef]

138. Li, L.; Renier, G. The Connection Between C-Reactive Protein (CRP) and Diabetic Vasculopathy. Focus on Preclinical Findings. Curr. Diabetes Rev. 2010, 6, 27-34. [CrossRef]

139. Mai, J.; Virtue, A.; Shen, J.; Wang, H.; Yang, X.-F. An Evolving New Paradigm: Endothelial Cells-Conditional Innate Immune Cells. J. Hematol. Oncol. 2013, 6, 61. [CrossRef] [PubMed]

140. Erlandsson, H.H.; Andersson, U. Mini-Review: The Nuclear Protein hmgb1 as a Proinflammatory Mediator. Eur. J. Immunol. 2004, 34, 1503-1512. [CrossRef] [PubMed]

141. Kalinina, N.; Agrotis, A.; Tararak, E.; Antropova, Y.; Kanellakis, P.; Ilyinskaya, O.; Bobik, A. Increased Expression of the DnaBinding Cytokine HMBG1 in Human Atherosclerotic Lesions: Role of Activated Macrophages and Cytokines. Cardiovasc. Pathol. 2004, 13, 97-98. [CrossRef]

142. Biscetti, F.; Straface, G.; De Cristofaro, R.; Lancellotti, S.; Rizzo, P.; Arena, V.; Stigliano, E.; Pecorini, G.; Egashira, K.; De Angelis, G.; et al. High-Mobility Group Box-1 Protein Promotes Angiogenesis After Peripheral Ischemia in Diabetic Mice Through a VEGF-Dependent Mechanism. Diabetes 2010, 59, 1496-1505. [CrossRef] [PubMed]

143. Oozawa, S.; Sano, S.; Nishibori, M. Usefulness of High Mobility Group Box 1 Protein as a Plasma Biomarker in Patient with Peripheral Artery Disease. Acta Med. Okayama 2014, 68, 157-162. [PubMed]

144. Biscetti, F.; Nardella, E.; Cecchini, A.L.; Flex, A.; Landolfi, R. Biomarkers of Vascular Disease in Diabetes: The Adipose-Immune System Cross Talk. Intern. Emerg. Med. 2020, 15, 381-393. [CrossRef]

145. Hajer, G.R.; Van Haeften, T.W.; Visseren, F.L.J. Adipose Tissue Dysfunction in Obesity, Diabetes, and Vascular Diseases. Eur. Hear. J. 2008, 29, 2959-2971. [CrossRef] [PubMed]

146. Biscetti, F.; Nardella, E.; Bonadia, N.; Angelini, F.; Pitocco, D.; Santoliquido, A.; Filipponi, M.; Landolfi, R.; Flex, A. Association between Plasma Omentin-1 Levels in Type 2 Diabetic Patients and Peripheral Artery Disease. Cardiovasc. Diabetol. 2019, 18, 74-77. [CrossRef]

147. Biscetti, F.; Nardella, E.; Rando, M.M.; Cecchini, A.L.; Angelini, F.; Cina, A.; Iezzi, R.; Filipponi, M.; Santoliquido, A.; Pitocco, D.; et al. Association between Omentin-1 and Major Cardiovascular Events after Lower Extremity Endovascular Revascularization in DI-Abetic Patients: A Prospective Cohort Study. Cardiovasc. Diabetol. 2020, 19, 1-11. [CrossRef]

148. Patel, K.M.; Strong, A.; Tohyama, J.; Jin, X.; Morales, C.R.; Billheimer, J.; Millar, J.; Kruth, H.; Rader, D.J. Macrophage Sortilin Promotes LDL Uptake, Foam Cell Formation, and Atherosclerosis. Circ. Res. 2015, 116, 789-796. [CrossRef]

149. Ogawa, K.; Ueno, T.; Iwasaki, T.; Kujiraoka, T.; Ishihara, M.; Kunimoto, S.; Takayama, T.; Kanai, T.; Hirayama, A.; Hattori, H. Soluble Sortilin Is Released by Activated Platelets and Its Circulating Levels Are Associated with Cardiovascular Risk Factors. Atherosclerosis 2016, 249, 110-115. [CrossRef]

150. Goettsch, C.; Kjolby, M.; Aikawa, E. Sortilin and Its Multiple Roles in Cardiovascular and Metabolic Diseases. Arter. Thromb. Vasc. Biol. 2018, 38, 19-25. [CrossRef]

151. Biscetti, F.; Bonadia, N.; Santini, F.; Angelini, F.; Nardella, E.; Pitocco, D.; Santoliquido, A.; Filipponi, M.; Landolfi, R.; Flex, A. Sortilin Levels Are Associated with Peripheral Arterial Disease in Type 2 Diabetic Subjects. Cardiovasc. Diabetol. 2019, 18, 1-8. [CrossRef] [PubMed] 
152. Biscetti, F.; Nardella, E.; Rando, M.M.; Cecchini, A.L.; Bonadia, N.; Bruno, P.; Angelini, F.; Di Stasi, C.; Contegiacomo, A.; Santoliquido, A.; et al. Sortilin Levels Correlate with Major Cardiovascular Events of Diabetic Patients with Peripheral Artery Disease Following Revas-Cularization: A Prospective Study. Cardiovasc. Diabetol. 2020, 19, 1-11. [CrossRef] [PubMed]

153. Venermo, M.; Sprynger, M.; Desormais, I.; Björck, M.; Brodmann, M.; Cohnert, T.; De Carlo, M.; Espinola-Klein, C.; Kownator, S.; Mazzolai, L.; et al. Follow-up of Patients after Revascularisation for Peripheral Arterial Diseases: A Consensus Document from the European Socie-Ty of Cardiology Working Group on Aorta and Peripheral Vascular Diseases and the European Society for Vascular Surgery. Eur. J. Prev. Cardiol. 2019, 26, 1971-1984. [CrossRef] [PubMed]

154. Humphries, M.D.; Pevec, W.C.; Laird, J.R.; Yeo, K.K.; Hedayati, N.; Dawson, D.L. Early Duplex Scanning after Infrainguinal Endovascular Therapy. J. Vasc. Surg. 2011, 53, 353-358. [CrossRef]

155. Baril, D.T.; Rhee, R.Y.; Kim, J.; Makaroun, M.S.; Chaer, R.A.; Marone, L.K. Duplex Criteria for Determination of in-Stent Stenosis after Angioplasty and Stenting of the Superficial Femoral Artery. J. Vasc. Surg. 2009, 49, 133-139. [CrossRef]

156. Saarinen, E.; Laukontaus, S.; Albäck, A.; Venermo, M. Duplex Surveillance After Endovascular Revascularisation for Critical Limb Ischaemia. Eur. J. Vasc. Endovasc. Surg. 2014, 47, 418-421. [CrossRef] [PubMed]

157. CAPRIE Steering Committee. A Randomised, Blinded, Trial of Clopidogrel versus Aspirin in Patients at Risk of Ischaemic Events (Caprie). Caprie Steering Committee. Lancet 1996, 348, 1329-1339. [CrossRef]

158. Bhatt, D.L.; Fox, K.A.; Hacke, W.; Berger, P.B.; Black, H.R.; Boden, W.E.; Cacoub, P.; Cohen, E.A.; Creager, M.A.; Easton, J.D.; et al. Clopidogrel and Aspirin versus Aspirin Alone for the Prevention of Atherothrombotic Events. N. Engl. J. Med. 2006, 354, 1706-1717. [CrossRef]

159. Cassar, K.; Ford, I.; Greaves, M.; Bachoo, P.; Brittenden, J. Randomized Clinical Trial of the Antiplatelet Effects of AspirinClopidogrel Combination versus Aspirin Alone after Lower Limb Angioplasty. Br. J. Surg. 2005, 92, 159-165. [CrossRef]

160. Tepe, G.; Bantleon, R.; Brechtel, K.F.M.; Schmehl, J.-M.; Zeller, T.; Claussen, C.D.; Strobl, F.F.X. Management of Peripheral Arterial Interventions with Mono or Dual Antiplatelet Therapy—-the MIRROR Study: A Randomised and Double-Blinded Clinical Trial. Eur. Radiol. 2012, 22, 1998-2006. [CrossRef] 